MINERAL MINING

TECHNOLOGY

\title{
Optimization of Grading of Sand in Backfill Using Metallurgical Waste
}

\author{
T. I. Rubashkina ${ }^{a *}$ and M. A. Korneichuk ${ }^{a}$ \\ ${ }^{a}$ Belgorod State University, Belgorod, 308015 Russia \\ *e-mail: rubashkina@bsu.edu.ru
}

Received May 17, 2020

Revised June 24, 2020

Accepted September 11, 2020

\begin{abstract}
It is technologically and economically advisable to optimize grading of low-quality fine and very fine sand with increased content of clay and dust particles used in preparation of cemented backfill mixtures by adding blast-furnace granular slag screenings $0-5 \mathrm{~mm}$ in size without preliminary treatment. The relationships of the size modulus, specific grain area and clay/dust particle content of sand and the percentage of slag in the composite aggregate are obtained. It is found that with increasing percentage of slag in the composite aggregate, water demand lowers owing to the higher size modulus of the aggregate and due to the decreased content of clay particles in it. This allows production of cemented backfill mixtures at the decreased consumption of cement while the strength and flowability of the mixtures are preserved.
\end{abstract}

Keywords: Cemented backfill, blast-furnace granular slag screenings, aggregate grading, cemented backfill strength, backfill fiowability.

DOI: $10.1134 / \mathrm{S} 1062739120057130$

The use of top-downward mining with cemented paste backfill imposes higher standards on rheology and strength of backfill mixtures. Rheological properties of a cemented past backfill should ensure sustainable flow along a backfill pipeline, without demixing and with uniform spreading in a room; strength characteristics should provide standard strength and stability of the backfill by the moment of exposure. Moreover, when formulating compositions of various cemented paste backfills, the cost of backfilling and the present strength time are taken into account.

Cemented paste backfill mixtures are prepared using conventional building materials (sand, cement, sand-and-gravel, etc.) and various production waste (steelmaking slag, blast-furnace slag, processing, waste, heat power plant fly-ash, etc.), which imposes certain, ecological, economic and other constraints on the cemented paste backfill mix composition.

A choice of materials for preparing cemented paste backfill mixtures is governed by many factors, including availability of sufficient material in close vicinity of a backfill plant, price of such material, its physical/mechanical/chemical properties, and features of its pretreatment (crushing, milling, screening, etc.). At the same time, it is difficult to find materials at the optimal price-quality relationship, and for this reason, for the purpose of haulage cost saving, local materials are most often selected, although they are shot of any quality standards.

The subject of this research us fine and very fine natural sand with the fineness modulus $M_{k}$ less than 0.7 , and with the increased (more than $15 \%$ ) content of clay and dust particles. Such sand is inapplicable as an aggregate in preparation of cement concrete and grouting as it falls short of standard GOST 8736 [1] in terms of grain size composition $\left(M_{k}\right.$ should be higher than 1.5) and content of clay and dust particles (their content is allowed not more than $10 \%$ in fine and very fine 
sand with the fineness modulus under 0.7). These limitations of the fineness modulus and content of clay and dust particles (size less than $0.16 \mathrm{~mm}$ ) are conditioned by practice and abundant research [2-7]. At the sand fineness modulus reduced by 0.1 , the cement consumption increased by 3-5\% [2]. With the increased fineness of the aggregate, the grain-cement matrix adhesion area grows, which results in the higher consumption of water to moisten the grains and in the higher consumption of cement to preserve strength $[2,3]$. The optimized specific area varies from $2 \mathrm{~m}^{2} / \mathrm{kg}$ for coarse sand to $15 \mathrm{~m}^{2} / \mathrm{kg}$ for fine sand [4-7]. The strength of cemented paste mixtures gets lower with the increased content of clay and dust particles in sand as the latter reduce adhesion between sand and cement.

Despite the adverse effect of increased fineness and higher clay content on the mixture strength and cement consumption, fine and very fine sand is used in production of cemented paste backfill. The cemented sand-and-cement backfill has a similar composition as cement concrete and cement grouting have, as the latter include Portland cement as a binder, sand as an aggregate, water and chemical and mineral additives. Some features of backfill mixtures allow using low-grade aggregates.

The mode of gravity flow of backfill mixture for large distances (to $3 \mathrm{~km}$ ) in pipelines dictates that the mixtures possess higher flowability (not less than $13-14 \mathrm{~cm}$ in the fiow cone tests [8] or $220 \mathrm{~m}$ in the Suttard viscosity tests). In order to reach such flowability and to prevent demixing along the whole pipeline toward the mixture placement point, the compositions of the mixtures are selected at the higher water-to-cement ratio as compared with cement concrete and cement grouting ( $\mathrm{W} / \mathrm{C}=1.2-1.3$ ) and at the increased (to $30 \%$ ) content of clay and dust particles in the aggregate. Clay interacts with water and swell, the volume and viscosity of clay suspension grow, and clay particles occur suspended for some time. On the one hand, this improves uniformity and cohesion of cemented paste backfills made of aggregates with increased content of clay; on the other hand, swelling and viscosity growth are the dynamic processes, and flowability of cemented paste backfills made of sand with increased content of clay markedly lowers with time. In order to preserve theological properties of cemented paste backfill mixture during gravity flow toward a placement point, it is necessary to increase water consumption and also to increase binder consumption (to keep strength of the mixture) or to add chemicals [8].

Depending on a backfill technology in use in a mine, the strength of a cemented paste backfill may range from 0.5 to $10 \mathrm{MPa}$. Such strength is achievable both with unconventional aggregate and increased consumption of Portland cement.

The objective of reduced consumption of expensive Portland cement at the preserved rheology and strength of cemented paste backfill mixture made using various nonconventional aggregate can be achieved by different ways: introduction of an integrated binder with substitution of come cement for slag-based additives, milled blast-furnace slag, heat power plant fiy-ash, zeolite and other kind waste; introduction of plastifies, modifies and other additives which reduce water consumption, etc.

In order to reduce consumption of expensive Portland cement in backfill mixture production, it can be partly replaced by milled blast-furnace slag [9-16]. Calcium silicates present in the mineral composition of blast-furnace slag impart the milled slag with weak binding properties, which can be utilized in the integrated binder production. At the same time, the fineness of the slag grind should be comparable with the fineness of the cement grind, which invites extra expenses in preparation of an integrated binder. On the other hand, in case of saving of some Portland cement, the total consumption of the integrated binder and, accordingly, mixing water, can remain the same or even grow if very fine aggregates are used. 
The aim of this study is to reduce cement consumption in backfill mixtures made of nonconventional fine and very fine sand through improvement of the quality of the latter, which means optimization of the grain size composition by means of enlargement of the fineness modulus, increase of the specific area of grains, and decrease in the content of clay and dust particles.

The fineness modulus of sand can be increased by screening of fines or by adding of coarser size. It is inefficient to screen fines from fine and very fine sand as its content in such sand reaches $40-80 \%$; for this reason, we select the second way-introduction of coarse material, of the same (or similar) density (true or bulk) and without clay components.

The optimization scenarios of grain size compositions of fine and very find sand were implemented using sand from Bolshie Mayachki deposit in the Belgorod Region. This natural sand can be red, white, beige and green in color. Red and white sand features the worst quality (the fineness modulus is less than 0.7 and the content of clay particles is from 10 to $18 \%$ ). We took these kinds of sand for the tests. The coarser agent is selected granulated blast-furnace slag siftings of 0-5 mm from Severstal (Cherepovets). The binder was chosen to be Portland cement with cement slag TSEM II/A-SH 32.5 N (Belgorod Cement Company), class 32.5.

The main physicotechnical properties of sand and slag (grain size composition, fineness modulus, content of clay and dust particles, true and bulk specific density) were determined in the certified laboratory at the Belgorod National University using standard procedures [17]. The theoretical specific area of initial sand and slag, $S_{\mathrm{sp}}^{T}\left(\mathrm{~m}^{2} / \mathrm{kg}\right)$, was calculated using the state standard [18]. The properties of the initial materials, determined from the tests, are compiled in Table 1.

Initial sand has a very low fineness modulus: -0.60 and 0.73 . Sand contains mostly fine and dust particles (smaller than $0.16 \mathrm{~mm}$ ); the content of clay particles is very high, and, as a consequence, the specific area of particles is very high, too. Such aggregate is inapplicable for preparing cemented paste backfill as it requires the increased consumption of water and cement, probably of higher strength, to moisten and bond these prevailing very fine sizes.

Table 1. Physicotechnical properties of Bolshie Mayachki sand and Severstal blast-furnace slag siftings

\begin{tabular}{|c|c|c|c|c|c|c|c|c|c|c|}
\hline \multirow[b]{2}{*}{ Material } & \multicolumn{6}{|c|}{ Undersize, wt $\%$, in screening with different sieve mesh, $\mathrm{mm}$} & \multirow[b]{2}{*}{$\begin{array}{l}\text { Fineness } \\
\text { modulus }\end{array}$} & \multirow[b]{2}{*}{$\begin{array}{l}C \\
\%\end{array}$} & \multirow[b]{2}{*}{$\underset{\mathrm{kg} / \mathrm{m}^{2}}{T}$} & \multirow[b]{2}{*}{$\underset{\mathrm{kg} / \mathrm{m}^{3}}{I,}$} \\
\hline & 2.50 & 1.25 & 0.63 & 0.315 & 0.16 & $\begin{array}{c}<0.16 \\
\text { including } \\
\text { clay }\end{array}$ & & & & \\
\hline $\begin{array}{l}\text { Sand no. } 1 \\
\text { (white) }\end{array}$ & $\begin{array}{l}0.07 \\
0.07\end{array}$ & $\begin{array}{l}0.04 \\
0.11\end{array}$ & $\begin{array}{l}5.46 \\
5.57\end{array}$ & $\begin{array}{c}\text { Partia } \\
4.65 \\
\text { Total } \\
10.22\end{array}$ & $\begin{array}{r}33.66 \\
43.88\end{array}$ & 56.12 & $\begin{array}{c}\text { Very fine } \\
0.60\end{array}$ & 18.29 & 19.45 & $\begin{array}{c}2675 / \\
1630\end{array}$ \\
\hline $\begin{array}{l}\text { Sand no. } 2 \\
\text { (red) }\end{array}$ & $\begin{array}{l}0.11 \\
0.11\end{array}$ & $\begin{array}{l}0.14 \\
0.25\end{array}$ & $\begin{array}{l}0.81 \\
1.06\end{array}$ & $\begin{array}{l}\text { Partia } \\
3.24 \\
\text { Total } \\
4.30\end{array}$ & $\begin{array}{l}62.52 \\
66.82\end{array}$ & 33.18 & $\begin{array}{l}\text { Fine } \\
0.73\end{array}$ & 10.07 & 15.53 & $\begin{array}{c}2600 / \\
1590\end{array}$ \\
\hline Red & $\begin{array}{l}2.07 \\
2.07\end{array}$ & $\begin{array}{r}10.63 \\
12.70\end{array}$ & $\begin{array}{l}52.35 \\
65.06 \\
\end{array}$ & $\begin{array}{c}24.40 \\
\text { Total } \\
89.46\end{array}$ & $\begin{array}{r}6.39 \\
95.85\end{array}$ & 4.15 & $\begin{array}{c}\text { Coarse } \\
2.65\end{array}$ & - & 7.69 & $\begin{array}{l}2700 / \\
1490\end{array}$ \\
\hline
\end{tabular}

$C$ - content of clay and dust particles; $T$-theoretical specific area; $I$-true/bulk specific density. 
Slag has values of coarse sand, is free from clay, features the specific area of particles 2.0-2.5 times lower than sand has, needs no pretreatment (sifting, grinding, etc.) and has a comparatively low cost. Moreover, the initial sand and slag have similar values of the true density, which simplifies selection of compositions of antifloating backfill mixtures.

This research aims to improve the initial sand up to the standard quality parameters, which means addition of coarser slag to elevate the fineness modulus up to 1.5 and higher. Sag was added in the composition of the complex aggregate in quantity of $5-50 \%$ at a grading of $5 \%$. The grain size composition, fineness modulus, content of clay and dust particles and the specific area was determined in each composition using the procedures specified above. The research results are summarized in Table 2.

When fine and very find sand is replaced by the granulated blast-furnace slag siftings $0-5 \mathrm{~mm}$ in size, the fineness modulus of the aggregate grows while the specific area of grains, and the content of dust and clay particles lower in proportion to the percent of slag introduced (Table 2). In order to refine the sand up to the standard quality (fineness modulus of 1.5 and higher), it is necessary to add $40 \%$ and not less than $45 \%$ of slag siftings to fine and very fine sand, respectively. The fineness modulus of backfill mixtures is allowed to be lower in case of the required strength and rheological properties, and, consequently, the percentage of the slag in the complex aggregate decreases.

Table 2. Physicotechnical properties of improved complex aggregate

\begin{tabular}{|c|c|c|c|c|}
\hline \multicolumn{2}{|c|}{$\begin{array}{c}\text { Content of initial } \\
\text { components, \% }\end{array}$} & \multirow{2}{*}{$\begin{array}{l}\text { Fineness } \\
\text { modulus }\end{array}$} & \multirow{2}{*}{$\begin{array}{l}\text { Content of clay and dust } \\
\text { particles, } \%\end{array}$} & \multirow{2}{*}{$\begin{array}{l}\text { Theoretical specific area, } \\
\mathrm{kg} / \mathrm{m}^{2}\end{array}$} \\
\hline Sand & Slag & & & \\
\hline \multicolumn{5}{|c|}{ Sand no. 1 (white) } \\
\hline 100 & 0 & 0.60 & 18.29 & 19.45 \\
\hline 95 & 5 & 0.70 & 17.37 & 19.11 \\
\hline 90 & 10 & 0.80 & 16.46 & 18.75 \\
\hline 85 & 15 & 0.91 & 15.54 & 18.38 \\
\hline 80 & 20 & 1.01 & 14.63 & 17.99 \\
\hline 75 & 25 & 1.11 & 13.71 & 17.58 \\
\hline 70 & 30 & 1.21 & 12.80 & 17.15 \\
\hline 65 & 35 & 1.32 & 11.89 & 16.70 \\
\hline 60 & 40 & 1.42 & 10.97 & 16.23 \\
\hline 55 & 45 & 1.52 & 10.06 & 15.73 \\
\hline 50 & 50 & 1.62 & 9.14 & 15.20 \\
\hline \multicolumn{5}{|c|}{ Sand no. 2 (red) } \\
\hline 100 & 0 & 0.73 & 10.07 & 15.53 \\
\hline 95 & 5 & 0.82 & 9.56 & 15.30 \\
\hline 90 & 10 & 0.92 & 9.06 & 15.06 \\
\hline 85 & 15 & 1.01 & 8.56 & 14.82 \\
\hline 80 & 20 & 1.11 & 8.05 & 14.56 \\
\hline 75 & 25 & 1.21 & 7.55 & 14.28 \\
\hline 70 & 30 & 1.30 & 7.05 & 14.00 \\
\hline 65 & 35 & 1.40 & 6.54 & 13.70 \\
\hline 60 & 40 & 1.50 & 6.04 & 13.57 \\
\hline 55 & 45 & 1.59 & 5.54 & 13.05 \\
\hline 50 & 50 & 1.69 & 5.03 & 12.70 \\
\hline
\end{tabular}


The curves of the complex aggregate fineness modulus and the dose of slag introduced in case of fine (red) and very fine (white) sand in Fig. 1 are parallel and have the same linear character $y=a+b x$. The mathematical analysis of these curves shows that $a$ equals the initial sand fineness modulus $M_{k 1}$, and $b$ is the tangent of angle of these curves, which is numerically equal to the difference between the fineness moduli of slag, $M_{k 2}$, and initial sand $\left(b=M_{k 2}-M_{k 1}\right)$.

In this manner, the formula was obtained for finding the fineness modulus of an complex aggregate made of fine and very fine sand as function of introduced siftings of granulated blast-furnace slag:

$$
M_{k 3}=M_{k 1}+\left(M_{k 2}-M_{k 1}\right) N \text {. }
$$

Here, $M_{k 3}$ is the fineness modulus of complex aggregate; $N$ is the dose of granulated blast-furnace slag in the complex aggregate (unit fractions). Placement of $M_{k 1}=0.6, M_{k 2}=2.65$ and $N=0.25$ in the formula produces $M_{k 3}=1.11$, which agrees with the experimental data (Table 2). The quantity of slag to be added to the complex aggregate to have the preset size composition (fineness modulus) can be calculated from transformed formula with respect to $N: N=\left(M_{k 3}-M_{k 1}\right) /\left(M_{k 2}-M_{k 1}\right)$.

The influence of optimization coarsening of fine and very fine sand on the rheological properties and strength characteristics of cemented paste backfill was tested on a laboratory scale using specially prepared mixtures - reference mixtures made of initial sand and test mixtures made of the complex aggregate.

For the tests we selected equally flowable backfill mixtures with the design strength of $3 \mathrm{MPa}$ and water/cement ratio $\mathrm{W} / \mathrm{C}=1.3$. The rheological properties of the experimental mixtures were determined using standard procedures and made: flow spread of $220 \mathrm{~mm}$ from Suttard's viscometer tests; ultimate shear stress less than $180 \mathrm{~Pa}$ by Shternbek's technique; stratifiability index (from the ratio of the ultimate shear stress of the mixture in the bottom cylinder to the ultimate shear stress of the mixture in the top cylinder) less than 1.3.

It is found that in the cone flow tests using Suttard's viscometer with a diameter of $220 \mathrm{~m}$ and a center height of $5 \mathrm{~mm}$, the tangent of the flow angle is 0.044 , which agrees with the flow angle of $2.5^{\circ}$. The density of the test mixtures and water segregation were determined in $1.5 \mathrm{~h}$ of settling the uniaxial compression tests were carried out on cubic samples $70.7 \times 70.7 \times 70.7 \mathrm{~mm}$ after normal mode curing with regard to the size correction factor of 0.85 . Shrinkage of the cured samples made $3-4 \%$. The results are summarized in Table 3. It is seen that with the large portion of slag in the complex aggregate, the water consumption and, consequently, the cement consumption reduce by $11-16 \%$. The adhesion (water segregation 1.2-2.8\%) and flowability (flow spread $220 \mathrm{~mm}$ ) of the mixture are preserved. The density and strength of the mixture made of the complex aggregate exceed the same characteristics of the reference mixtures (without slag) by $20 \%$.

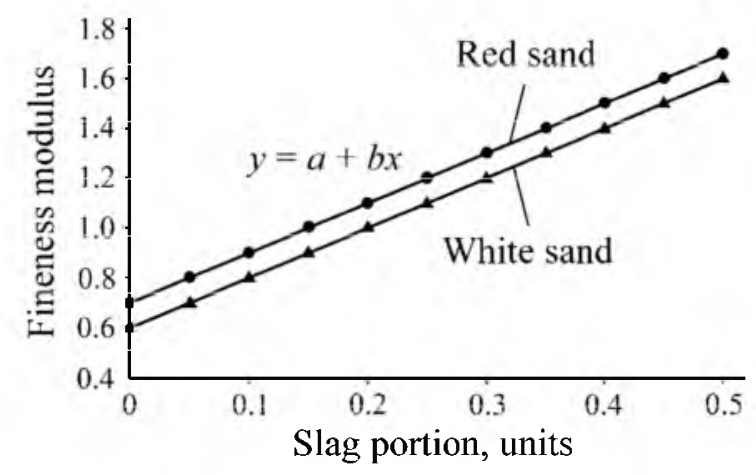

Fig. 1. Fineness modulus versus slag addition to complex aggregate. 
Table 3. Compositions of backfill mixtures with optimized aggregate

\begin{tabular}{|c|c|c|c|c|c|c|c|c|}
\hline \multicolumn{2}{|c|}{$\begin{array}{c}\text { Aggregate } \\
\text { composition, \% }\end{array}$} & \multicolumn{3}{|c|}{$\begin{array}{c}\text { Consumption per } 1 \mathrm{~m}^{3} \\
\text { of mixture, } \mathrm{kg}<\end{array}$} & \multirow{2}{*}{$\begin{array}{l}\text { Reduction in } \\
\text { consumption } \\
\text { of cement } \\
\text { and water, \% }\end{array}$} & \multirow{2}{*}{$\begin{array}{l}\text { Mixture } \\
\text { density, } \\
\mathrm{kg} / \mathrm{m}^{3}\end{array}$} & \multirow{2}{*}{$\begin{array}{c}\text { Water } \\
\text { segregation, } \\
\%\end{array}$} & \multirow{2}{*}{$\begin{array}{c}\text { Strength, } \\
\mathrm{MPa} \\
\text { (28 days) }\end{array}$} \\
\hline Sand & Slag & Cement & Aggregate & Water & & & & \\
\hline \multicolumn{9}{|c|}{ Sand no. 1 (white) } \\
\hline 100 & 0 & 380 & 1026 & 494 & - & 1828 & 2.8 & 3.00 \\
\hline 95 & 5 & 376 & 1043 & 489 & 1.05 & 1908 & 2.8 & 3.06 \\
\hline 90 & 10 & 373 & 1056 & 485 & 1.84 & 1914 & 2.8 & 3.12 \\
\hline 85 & 15 & 369 & 1073 & 480 & 2.89 & 1922 & 2.7 & 3.18 \\
\hline 80 & 20 & 366 & 1086 & 476 & 3.68 & 1928 & 2.7 & 3.24 \\
\hline 75 & 25 & 363 & 1099 & 472 & 4.47 & 1934 & 2.6 & 3.30 \\
\hline 70 & 30 & 360 & 1112 & 468 & 5.26 & 1940 & 2.6 & 3.37 \\
\hline 65 & 35 & 355 & 1134 & 462 & 6.58 & 1951 & 2.6 & 3.43 \\
\hline 60 & 40 & 350 & 1156 & 455 & 7.89 & 1961 & 2.5 & 3.50 \\
\hline 55 & 45 & 345 & 1178 & 449 & 9.21 & 1971 & 2.5 & 3.57 \\
\hline 50 & 50 & 335 & 1221 & 436 & 11.84 & 1991 & 2.3 & 3.64 \\
\hline \multicolumn{9}{|c|}{ Sand no. 2 (red) } \\
\hline 100 & 0 & 370 & 1062 & 480 & - & 1912 & 2.5 & 3.40 \\
\hline 95 & 5 & 364 & 1089 & 472 & 1.73 & 1924 & 2.5 & 3.46 \\
\hline 90 & 10 & 357 & 1116 & 464 & 3.43 & 1937 & 2.3 & 3.53 \\
\hline 85 & 15 & 351 & 1143 & 456 & 5.10 & 1949 & 2.2 & 3.59 \\
\hline 80 & 20 & 345 & 1169 & 448 & 6.74 & 1961 & 2.2 & 3.66 \\
\hline 75 & 25 & 339 & 1194 & 440 & 8.35 & 1973 & 2.2 & 3.73 \\
\hline 70 & 30 & 333 & 1220 & 432 & 9.94 & 1985 & 2.0 & 3.80 \\
\hline 65 & 35 & 327 & 1244 & 425 & 11.50 & 1997 & 2.0 & 3.87 \\
\hline 60 & 40 & 322 & 1269 & 417 & 13.03 & 2008 & 1.8 & 3.94 \\
\hline 55 & 45 & 316 & 1293 & 410 & 14.53 & 2019 & 1.6 & 4.01 \\
\hline 50 & 50 & 311 & 1316 & 403 & 16.01 & 2030 & 1.2 & 4.08 \\
\hline
\end{tabular}

The economic efficiency of fine and very fine sand optimization by adding granulated blastfurnace slag siftings was evaluated from the total cost of solid materials (Portland cement, sand, slag) per 1 cubic meter of the prepared backfill mixture (Fig. 2). As no special treatment of slag (milling, screening, drying, etc.) or no major redesign of the mixture preparation and gravity flow chart is required, the energy and other cost included in the cost of backfilling are assumed as constant. The evaluation used market prices of the materials, in the ranges subject to suppliers: Portland cement $3900-5100 \mathrm{Rub} / \mathrm{t}$; fine sand $80-150 \mathrm{Rub} / \mathrm{t}$; granulated blast-furnace slag sifting size $0-5 \mathrm{~mm} \mathrm{90-200} \mathrm{Rub/t}$. The calculations use the minimal prices of 3900 and $80 \mathrm{Rub} / \mathrm{t}$ for Portland cement and sand, respectively, and the maximal price of $200 \mathrm{Rub} / \mathrm{t}$ for slag.

The calculation show that despite the double the price of slag as against fine sand, the total price of solid per $1 \mathrm{~m}^{3}$ of backfill mixture reduces with the increasing portion of slag in the aggregate. 


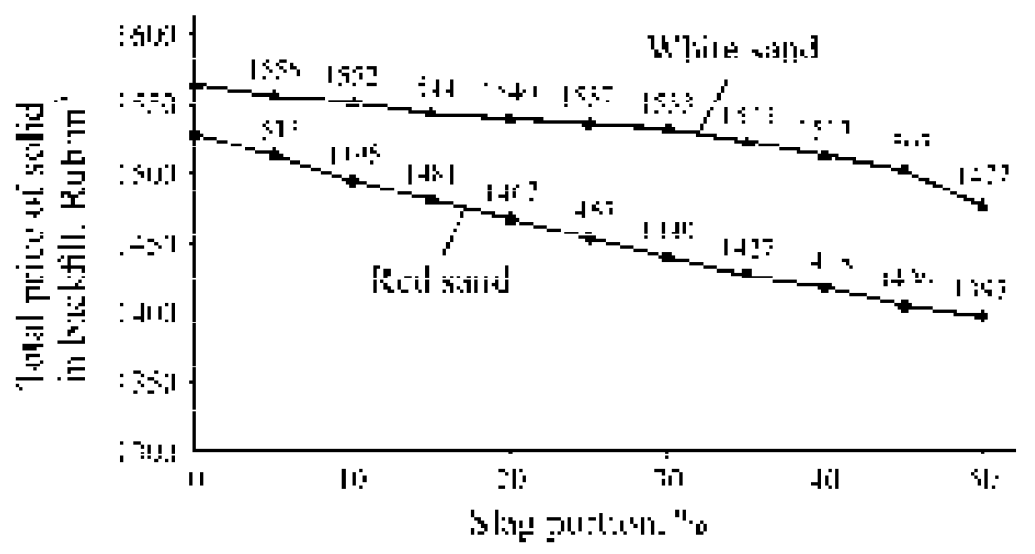

Fig. 2. Total price of solid (Portland cement, sand, slag) per $1 \mathrm{~m}^{3}$ of backfill mixture depending on portion of slag in aggregate.

For the economic evaluation of the grain size composition improvement in low-grade fine and very fine sand with the increased content of dust and clay particles by means of addition of granulated blast-furnace slag sifting size $0-5 \mathrm{~mm}$, in case of each composition (Table 3), NPV was calculated based on the profit (saving) due to the reduced total price of solid in $1 \mathrm{~m}^{3}$ of backfill with regard to a discount rate of 0.2 (including expected inflation rate of 3\%; risk as the expected efficiency gap because of increased prices of materials and haulage 10\%; long-term interest 4-7\%). The calculation results are depicted in Fig. 3. The efficiency elevates owing to the better quality of the aggregateoptimization of grain size composition and decreased content of dust and clay particles. The price of $1 \mathrm{t}$ of the cheapest Portland cement is desperately higher than the prices of sand and slag. For this reason, saving of $11-16 \%$ of Portland cement per every $1 \mathrm{~m}^{3}$ of cemented paste backfill mixtures, considering the volume of voids to be filled, is essential.

\section{CONCLUSIONS}

Metallurgical waste, namely, granulated blast-furnace slag $0-5 \mathrm{~mm}$ in size, with the fineness modulus of 2.65 is applicable in optimization of grain size composition of fine and very fine sand with higher content of clay. Addition of $40-45 \%$ of such slag siftings in fine and very fine sand increased the fineness modulus of the resultant complex aggregate to the standard value of cementand-sand paste backfill mixtures (1.5) and halves the content of clay and dust particles in it.

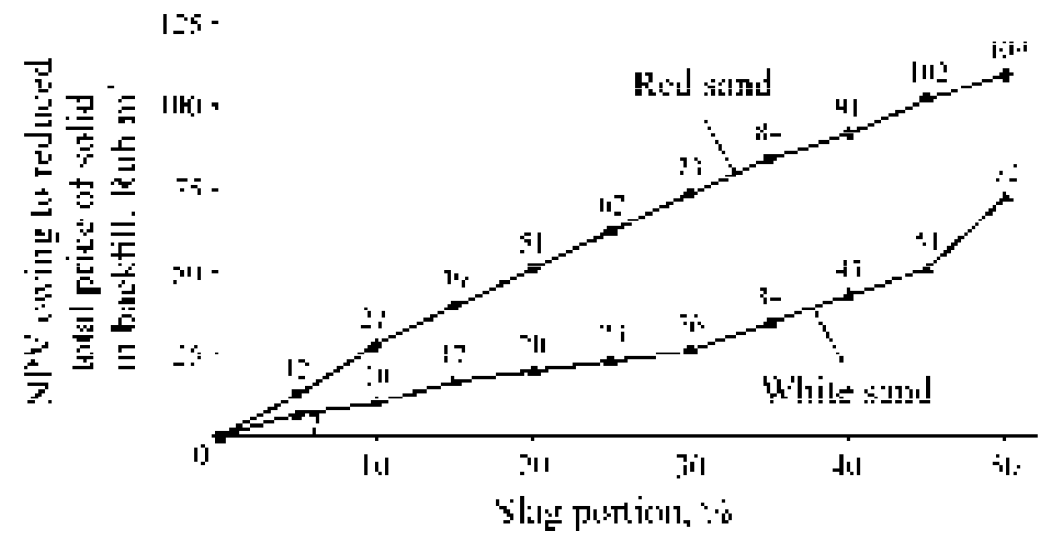

Fig. 3. NPV owing to reduced total price of solid (Portland cement, sand, slag) in $1 \mathrm{~m}^{3}$ of backfill mixture depending on slag portion in aggregate. 
Optimization of grain size composition of fine and very fine backfill sand through the increase of the fineness modulus allows the decreased water consumption by $11-16 \%$ and the production of cemented paste backfill mixtures with lower cement consumption by $11-16 \%$ at the preserved flowabilty and improved strength by $20 \%$.

The economic evaluation show that, given availability of sand with the fineness modulus less 0.7 for the production of cemented paste backfill and deliverability of the coarsening agent at minimal haulage cost, optimization of grain size composition of fine and very fine sand by addition of siftings of granulated blast-furnace slag is efficient and expedient.

\section{REFERENCES}

1. Russian Federation State Standard GOST 8736-2014, Moscow: Standartinform, 2019.

2. Bazhenov, Yu.M., Tekhnologiya betona (Technology of Concrete), Moscow: ASV, 2002.

3. Bazhenov, Yu.M. and Kharchenko, A.I., Fine-Grain Backfill Concrete Using Low-Grade Sand, Nauch.Tekhn. Vestn. Povolzhiya, 2012, no. 5, pp. 86-88.

4. Kosach, A.F., Influence of Specific Area of River Sand Particles on Physical and Mechanical Properties of Fine-Grain Concrete, Vestn. YuGU, 2012, no. 2 (25), pp. 34-36.

5. Kudryakov, A.I., Anikanova, L.A., Kopanitsa, N.O., and Gerasimov, A.V., Effect of Grain Sizes and Types of Aggregates on Properties of Mortars, Stroit. Materialy, 2001, no. 1, pp. $28-29$.

6. Mongush, S.Ch., Effect of Properties of Fine Aggregates on Quality of Concretes, Vestn. TuvGU, 2011, no. 3, pp. 4-8.

7. Khozin, V.G., Morozov, N.M., and Borovskikh, I.V., Optimization of Grain Size Composition of Sand for Fine-Grain Concrete Production, Izv. KazGASU, 2008, no. 2 (10), pp. 121-124.

8. Montyanova, A.N., Garkavi, M.S., and Kosova, N.S., Features and Efficiency of Additives in Backfill Mixtures, GIAB, 2009, no. 9, pp. 287-295.

9. Kalmykov, V.N. and Slashchilin, I.T., Applicability of Compound Binder Made of Cement and Granulated Blast-Furnace Slag of Severstal in Backfill Mixtures in Heavy-Mineral-Sand Operations at Yarega Mining and Chemical Works, GIAB, 2005, no. 1, pp. 182-187.

10. Vinogradov, S.A. and Kutuzov, V.I., Technology of Formulation and Preparation of Backfill Mixture for Yrage Mine, Gornyi Zhurnal, 1991, no. 10, pp. 31-35.

11. Gurevich, B.I. and Tyukavkina, V.V., Binders Made of Nonferrous Metallurgy Slag, Tsvet. Metallurg., 2007, no. 4, pp. 10-16.

12. Klassen, V.K., Morozova, I.A., Borisov, I.N., and Mandrikova, O.S., Energy Saving and Increasing the Strength of Cement Using Steel Slag as a Raw Material Component, Middle-East J. of Sci. Res., 2013, vol. 18 , no. 11, pp. 1597-1601.

13. Krupnik, L.A., Shaposhnik, Yu.N., Shaposhnik, S.N., Nurshaiykova, G.T., and Tungushbaeva, Z.K., Technology of Backfill Preparation Based on Cement-and-Slag Binder in Orlov Mine, J. Min. Sci., 2017, vol. 53, no. 1, pp. 77-83.

14. Algermissen, D and Ehrenberg, A., Applicability of Electric Furnace Steelmaking Slag as a Hydraulic Binder, Chern. Metally, 2018, no. 9, pp. 21-27.

15. Deng, D.Q., Liu, L., Yao, Z.L., Song, K.I., and Lao, D.Z., A Practice of Ultra-Fine Tailings Disposal as Filling Material in a Gold Mine, J. Environ. Manage., 2017, vol. 196, pp. 100-109.

16. Ke, X., Zhou, X., Wang, X., Wang, T., Hou, H., and Zhou, M., Effect of Tailings Fineness on the Pore Structure Development of Cemented Paste Backfill, Constr. Build. Mater., 2016, vol. 126, pp. 345-350.

17. USSR State Standard GOST 8735-88, Moscow: Standartinform, 2019.

18. Russian Federation State Standard GOST 29234.12-91, Moscow: Standartinform, 2019. 